\title{
Differential Contribution of the Guanylyl Cyclase-Cyclic GMP-Protein Kinase G Pathway to the Proliferation of Neural Stem Cells Stimulated by Nitric Oxide
}

\author{
Bruno P. Carreira ${ }^{a} \quad$ Maria Inês Morte ${ }^{a} \quad$ Ana Sofia Lourenço $^{a} \quad$ Ana Isabel Santos $^{a}$ \\ Ângela Inácio ${ }^{a}$ António F. Ambrósio ${ }^{a, b}$ Caetana M. Carvalho ${ }^{a}$ Inês M. Araújo ${ }^{a, c}$ \\ ${ }^{a}$ Centre for Neuroscience and Cell Biology, Neuroendocrinology and Neurogenesis Group and ${ }^{b}$ Centre of \\ Ophthalmology and Vision Sciences, IBILI, Faculty of Medicine, University of Coimbra, Coimbra, and ' Department \\ of Biomedical Sciences and Medicine, University of Algarve, Faro, Portugal
}

\section{Key Words}

Nitric oxide $\cdot$ Neural stem cells · cyclic GMP •

cGMP-dependent kinase - Proliferation - Neurogenesis •

Guanylyl cyclase

\begin{abstract}
Nitric oxide (NO) is an important inflammatory mediator involved in the initial boost in the proliferation of neural stem cells following brain injury. However, the mechanisms underlying the proliferative effect of NO are still unclear. The aim of this work was to investigate whether cyclic GMP (cGMP) and the CGMP-dependent kinase (PKG) are involved in the proliferative effect triggered by NO in neural stem cells. For this purpose, cultures of neural stem cells isolated from the mouse subventricular zone (SVZ) were used. We observed that long-term exposure to the NO donor ( $24 \mathrm{~h}$ ), NOC-18, increased the proliferation of SVZ cells in a cGMPdependent manner, since the guanylate cyclase inhibitor, $\mathrm{ODQ}$, prevented cell proliferation. Similarly to NOC-18, the cGMP analogue, 8-Br-cGMP, also increased cell proliferation. Interestingly, shorter exposures to NO (6 h) increased cell proliferation in a cGMP-independent manner via the ERK/
\end{abstract}

\section{KARGER}

E-Mail karger@karger.ch www.karger.com/nsg (c) 2012 S. Karger AG, Basel $1424-862 X / 13 / 0212-0001 \$ 38.00 / 0$

Karger

Open access

This is an Open Access article licensed under the terms of the Creative Commons Attribution-NonCommercialNoDerivs 3.0 License (www.karger.com/OA-license), applicable to the online version of the article only. Distribution for non-commercial purposes only.
MAP kinase pathway. The selective inhibitor of PKG, KT5823, prevented the proliferative effect induced by NO at $24 \mathrm{~h}$ but not at $6 \mathrm{~h}$. In conclusion, the proliferative effect of $\mathrm{NO}$ is initially mediated by the ERK/MAPK pathway, and at later stages by the GC/cGMP/PKG pathway. Thus, our work shows that $\mathrm{NO}$ induces neural stem cell proliferation by targeting these two pathways in a biphasic manner.

Copyright $\odot 2012$ S. Karger AG, Base

\section{Introduction}

An injury to the central nervous system often results in neuroinflammation, which is characterized by the activation of resident microglial cells, astrocytes, and eventually by infiltrating peripheral macrophages and lymphocytes, recently reviewed by Whitney et al. [1]. It is now well established that inflammation affects the formation of new cells following brain injury [2-4]. An acute brain insult, such as stroke, seizures, or trauma, often elicits a proliferative response from the neurogenic niches [5-9]. New cells are attracted to the lesioned areas in order to replace the lost neural cells [10]. Factors 
produced and released by immune cells during the neuroinflammatory response affect the proliferation, migration, and differentiation of neuronal precursors following a lesion $[11,12]$. Microglial cells can produce a wide range of pro- and anti-inflammatory mediators, which can differentially affect the different steps of neurogenesis $[2,3,13]$. Among such factors, nitric oxide (NO) is of particular interest given its notable features such as short half-life, diffusivity, and signaling properties [1].

$\mathrm{NO}$ is a free radical produced by $\mathrm{NO}$ synthases and a pleiotropic messenger in several biological processes [14]. Recent studies have shown the involvement of $\mathrm{NO}$ on neurogenesis, either in basal conditions or following an injury. Particularly, NO was described as a physiological inhibitor of neurogenesis in mice [15-18]. Other studies demonstrated that $\mathrm{NO}$ is important for the initial increase in proliferation of neural stem cells in the neurogenic niches following stroke [19] or seizures [20]. We recently showed that the NO donor 2,2'-(hydroxynitrosohydrazino)bis-ethanamine (NOC-18) can stimulate proliferation of isolated neural stem cells in culture when used in low doses (1-10 $\mu \mathrm{M})$ [20]. Nevertheless, the mechanisms underlying the proliferative effect of $\mathrm{NO}$ are not yet identified.

The main biological target of NO is the heme-containing enzyme guanylyl cyclase. Guanylyl cyclase catalyzes the conversion of GTP to cyclic GMP (cGMP), which in turn can act on further downstream targets such as the cGMP-dependent kinase (PKG) and cGMPgated channels. In a variety of cell types, NO and cGMP have been described as important effectors in several cellular processes, including survival, differentiation, growth, axon guidance or migration, through the activation of different downstream signaling cascades [21-23]. Neurogenesis is positively affected by cGMP and cGMPsparing agents such as sildenafil or tadalafil [21, 24-26]. However, it remains to be established whether cGMP and PKG are responsible for the proliferative effect of NO when applied to neural stem cells. Within this scenario, we investigated the role of the guanylyl cyclase-cGMPPKG pathway in the proliferative effect of NO. We observed that cGMP analogues mimic the effect of NO in increasing cell proliferation. Moreover, blocking guanylyl cyclase or PKG prevented the proliferative effect of $\mathrm{NO}$, thus pointing to the involvement of the NO-cGMP signaling pathway in the enhancement of neural stem cell proliferation.

\section{Materials and Methods}

\section{Materials}

Dulbecco's modified Eagle's medium:F-12 nutrient mixture (D-MEM/F-12, with GlutaMAX ${ }^{\mathrm{TM}}-\mathrm{I}$ ), B27 supplement, trypsinEDTA solution (0.05\% trypsin, 1 mM EDTA in Hanks balanced salt solution, antibiotic (10,000 units/ml penicillin, $10 \mathrm{mg} / \mathrm{ml}$ streptomycin), epidermal growth factor, basic fibroblast growth factor and Click-iT ${ }^{\circledR}$ EdU Alexa Fluor ${ }^{\circledR} 488$ Flow Cytometry Assay Kit were purchased from Invitrogen (Paisley, UK). 5-Bromo2'-deoxyuridine (BrdU), 8-bromoguanosine 3', $5^{\prime}$-cyclic monophosphate (8-Br-cGMP), phenylmethylsufonyl fluoride, dithiothreitol, orthovanadate, chymostatin, leuptin, antiparin, pepstatin A, trypan blue and 1,4-diamino-2,3-dicyano-1,4-bis(o-aminophenylmercapto)butadiene monoethanolate (U0126) were purchased from Sigma Chemical (St. Louis, Mo., USA). KT5823 was purchased from Alomone Labs (Jerusalem, Israel). 1H-[1,2,4] oxadiozolo[4,3-a]quinoxalin-1-one (ODQ) and zaprinast were obtained from Tocris Bioscience (Bristol, UK). Mouse anti-Sox-2 was purchased from R\&D Systems (Minneapolis, Minn., USA) and rabbit anti-nestin from Santa Cruz Biotechnology (Santa Cruz, Calif., USA). NOC-18 was obtained from Alexis Biochemicals (San Diego, Calif., USA). A DAKO fluorescence mounting medium was purchased from DakoCytomation (Glostrup, Denmark). Rat anti-mouse BrdU was obtained from Oxford Biotechnology (Oxford, UK). Hoechst 33342 dye, anti-rat IgG conjugated with Alexa Fluor 594, anti-mouse IgG conjugated with Alexa Fluor 594 and anti-rabbit IgG conjugated with Alexa Fluor 488 secondary antibodies were purchased from Molecular Probes (Leiden, The Netherlands). Polyvinylidene difluoride membranes, enhanced chemifluorescence reagent, cGMP BioTRAK, alkaline phosphatase-linked anti-rabbit and anti-mouse secondary antibodies were obtained from Amersham Pharmacia Biotech (Little Chalfont, UK). Monoclonal mouse anti-p44/42 MAPK (ERK1/2) and rabbit anti-phospho-ERK1/2 antibodies were obtained from Cell Signaling Technology (Danvers, Mass., USA). Other reagents used in immunoblotting experiments were purchased from BioRad (Hercules, Calif., USA).

\section{Animals}

C57BL/6J mice were obtained from Charles River (Barcelona, Spain) and kept with food and water ad libitum in a 12-hour dark:light cycle. All experiments were performed in accordance with the NIH and the European (86/609/EEC) guidelines for the care and use of laboratory animals.

\section{Subventricular Zone Neural Stem Cell Cultures}

Neural stem cell cultures were obtained from the subventricular zone (SVZ) of postnatal day 0-3 C57BL/6J mice, as previously described [20]. Briefly, the brains were removed from the skull following decapitation, and placed in a dissection medium composed of $\mathrm{Ca}^{2+}$ - and $\mathrm{Mg}^{2+}$-free Hanks balanced salt solution $(137 \mathrm{mM} \mathrm{NaCl}$, $5.36 \mathrm{mM} \mathrm{KCl}, 0.44 \mathrm{mM} \mathrm{KH}_{2} \mathrm{PO}_{4}, 0.34 \mathrm{mM} \mathrm{Na}_{2} \mathrm{PO}_{4} \cdot 2 \mathrm{H}_{2} \mathrm{O}, 4.16 \mathrm{mM}$ $\mathrm{NaHCO}_{3}, 5 \mathrm{~mm}$ glucose, $1 \mathrm{~mm}$ sodium pyruvate, $10 \mathrm{~mm}$ HEPES, $\mathrm{pH}$ 7.4), supplemented with $0.25 \%$ gentamicin. After removing the enveloping meninges, the cerebellum was discarded and the whole cortex tissue was cut in 450 - $\mu$ m-thick coronal sections using a MclLwain tissue chopper (The Mickle Laboratory Engineering Co. Ltd., Guildford, UK). The fragments of SVZ encompassing both ependymal and subependymal layers were digested in $0.025 \%$ tryp- 
sin and $0.265 \mathrm{~mm}$ EDTA for $20 \mathrm{~min}$ at $37^{\circ} \mathrm{C}$, and dissociated by gentle trituration with a pipette tip. Following dissociation, the cells were resuspended in fresh D-MEM/F-12 with GlutaMAX-I, supplemented with $1 \% \mathrm{~B} 27,1 \%$ antibiotic $(10,000$ units/ml penicillin, $10 \mathrm{mg} / \mathrm{ml}$ streptomycin), $10 \mathrm{ng} / \mathrm{ml}$ epidermal growth factor and $10 \mathrm{ng} / \mathrm{ml}$ basic fibroblast growth factor. Cells were then plated on uncoated Petri dishes at a density of $3,000 \mathrm{cells} / \mathrm{cm}^{2}$. The SVZ stem cells were grown as floating neurospheres in a $95 \%$ air $/ 5 \% \mathrm{CO}_{2}$ humidified atmosphere at $37^{\circ} \mathrm{C}$. Seven days following plating, the primary neurospheres were harvested, centrifuged and dissociated as single cells. Cells were then replated as above and allowed to grow as secondary neurospheres. Neurospheres with $2-4$ passages were collected and plated for 5 days on glass coverslips, $16 \mathrm{~mm}$ in diameter, for immunocytochemistry assays, or on 12-well plates, coated with poly-L-lysine, in a serum-free medium, without growth factors, for preparation of lysates or flow cytometry assays.

\section{Characterization of SVZ Primary Cultures}

SVZ-derived neural stem cells plated on poly-L-lysine-coated coverslips for 5 days (in a minimum of 3 independent experiments) were fixed with $4 \%$ paraformaldehyde $/ 4 \%$ sucrose in phosphate-buffered saline (PBS, $0.1 \mathrm{M}$ ). The cells were then permeabilized with $1 \%$ Triton X-100 for $5 \mathrm{~min}$. Nonspecific binding was blocked with 3\% BSA in $0.2 \%$ Tween 20 in PBS (PBS-T) for $1 \mathrm{~h}$, and cells were labeled with the primary antibodies mouse antiSox-2 (1:100) and rabbit anti-nestin (1:100) for $90 \mathrm{~min}$ at room temperature. The cells were then exposed to secondary antibodies anti-mouse and anti-rabbit IgGs conjugated with Alexa Fluor 594 and 488 (1:200), respectively, for $1 \mathrm{~h}$ at room temperature. Nuclei were stained with Hoechst $33342(1 \mu \mathrm{g} / \mathrm{ml})$ for $3 \mathrm{~min}$. Coverslips were mounted on glass slides using a DAKO fluorescence mounting medium. Images were acquired in a laser scanning microscope LSM 510 META (Zeiss, Jena, Germany).

\section{Experimental Treatments in SVZ Cell Cultures}

SVZ-derived neural stem cells were exposed to the NO donor NOC-18 $(10 \mu \mathrm{M})$ or to the cGMP analogue 8 -Br-cGMP $(20 \mu \mathrm{M})$ for different periods of time, as indicated in detail in the figure legends and in the text. The guanylyl cyclase inhibitor ODQ (50 $\mu \mathrm{M})$, the protein kinase $\mathrm{G}(\mathrm{PKG})$ inhibitor KT5823 $(1 \mu \mathrm{M})$ and the MEK1/2 inhibitor U0126 (1 $\mu \mathrm{M})$ were added $30 \mathrm{~min}$ before NOC18 or 8 -Br-cGMP and kept throughout the incubation period.

Decomposed NOC-18 was prepared by diluting a $10 \mathrm{mM} \mathrm{NOC-}$ 18 stock solution (prepared in $0.01 \mathrm{M} \mathrm{NaOH}$, which keeps NOC-18 from releasing $\mathrm{NO}$ in alkaline solutions) to $1 \mathrm{mM} \mathrm{NOC-18}$ in a culture medium ( $\mathrm{pH} 7.0$, since NOC-18 releases $\mathrm{NO}$ at this $\mathrm{pH}$ ), which was kept for $72 \mathrm{~h}$ at room temperature on a lab bench, unprotected from light. This solution was used to treat SVZ cultures in a final concentration of $10 \mu \mathrm{M}$ decomposed NOC-18, and experiments were run with fresh NOC-18.

\section{Determination of cGMP Levels}

The cGMP levels in SVZ-derived neural stem cell cultures were determined after exposure to drugs for 6 or $24 \mathrm{~h}$ using a cGMP enzyme immunoassay system (Amersham). All experiments were carried out in duplicate and in the presence of zaprinast $(50 \mu \mathrm{M})$, a phosphodiesterase inhibitor, as previously described [27]. Cell lysis and cGMP measurement were performed according to the manufacturer's instructions. The results are expressed as femtomoles per million cells.

Biphasic Stimulation of Neural Stem Cell

Proliferation by NO
Detection of Cell Proliferation and Cell Cycle Analysis by Flow Cytometry

SVZ cell proliferation was assessed by the incorporation of 5-ethynyl-2'-deoxyuridine (EdU) and detected by flow cytometry, using the Click-iT EdU Alexa Fluor 488 Flow Cytometry Assay Kit. EdU was added to the SVZ cultures $4 \mathrm{~h}$ before fixation. Fixation was performed with $70 \%$ ethanol overnight. Detection of EdU incorporation was based on click chemistry, a copper-catalyzed reaction between an azide (conjugated to a fluorophore) and an alkyne (EdU). Fixed cells were incubated for $30 \mathrm{~min}$ with Alexa Fluor 488 azide and copper sulfate. The cells were then incubated with RNase and the nuclear dye 7-actinomycin D (7-AAD) for 30 min. The cells were analyzed for EdU incorporation and nuclear staining on a FACScalibur using the Cellquest software (Becton Dickinson, San Jose, Calif., USA). Thirty thousand events were acquired per experiment. A minimum of 3 independent experiments were analyzed for each condition. The flow cytometer was calibrated with fluorescent standard microbeads (CaliBRITE Beads, BD Biosciences, San Jose, Calif., USA) for accurate instrument setting.

\section{Detection of BrdU Incorporation}

Cell proliferation was also assessed by the incorporation of the thymidine analogue BrdU, which is incorporated into the DNA of dividing cells during $S$ phase. BrdU $(10 \mu \mathrm{M})$ was added to the cultures $16 \mathrm{~h}$ before fixation $[20,28]$. Nuclei that incorporated $\mathrm{BrdU}$ in this time window were detected by immunofluorescence as follows: following $20 \mathrm{~min}$ fixation with $4 \%$ paraformaldehyde/4\% sucrose in PBS, the cells were permeabilized with $1 \%$ Triton X-100 for $5 \mathrm{~min}$, and DNA was denaturated by treatment with $1 \mathrm{M} \mathrm{HCl}$ for $30 \mathrm{~min}$ at $37^{\circ} \mathrm{C}$. Nonspecific binding was blocked with 3\% BSA in PBS-T for $1 \mathrm{~h}$, and then BrdU-positive cells were labeled with a rat anti-BrdU antibody (1:50) for $90 \mathrm{~min}$ at room temperature. The cells were then incubated with a secondary antibody goat anti-rat IgG conjugated with Alexa Fluor 594 (1:200) for $1 \mathrm{~h}$ at room temperature. Nuclei were stained with Hoechst $33342(1 \mu \mathrm{g} / \mathrm{ml})$ for $3 \mathrm{~min}$. Coverslips were mounted on glass slides using DAKO fluorescence mounting medium Dako Cytomation. The cells were visualized in a fluorescence microscope (Axioskop 2 Plus, Zeiss, Jena, Germany) and images were acquired with the Axiovision software 4.7. The number of BrdUpositive nuclei was counted in 7-10 randomly selected fields for each coverslip (in a total of approximately $900-1,200$ cells per coverslip), and the data were expressed as percentages of the total number of living cells. A minimum of 3 independent experiments were analyzed for each condition.

\section{Western Blot Analysis}

Cells were lysed in $50 \mathrm{~mm}$ Tris- $\mathrm{HCl}, 10 \mathrm{~mm}$ EGTA, 1\% Triton $\mathrm{X}-100$ and $2 \mathrm{mM} \mathrm{MgCl}_{2}$, supplemented with $100 \mu \mathrm{M}$ phenylmethylsufonyl fluoride, $1 \mathrm{~mm}$ dithiothreitol, $1 \mu \mathrm{g} / \mathrm{ml}$ chymostatin, $1 \mu \mathrm{g} / \mathrm{ml}$ leupeptin, $1 \mu \mathrm{g} / \mathrm{ml}$ antiparin, $5 \mu \mathrm{g} / \mathrm{ml}$ pepstatin $\mathrm{A}, 1 \mathrm{mM}$ sodium orthovanadate, and $50 \mathrm{~mm} \mathrm{NaF}, \mathrm{pH} \mathrm{7.4}$, at $4^{\circ} \mathrm{C}$. Protein concentration was determined by the bicinchoninic acid method (BCA ${ }^{\mathrm{TM}}$ Protein Assay kit, Pierce, Rockford, Ill., USA), and the samples were used for Western blot analysis, after adding $6 \times$ concentrated sample buffer $(0.5 \mathrm{M}$ Tris, $30 \%$ glycerol, $10 \%$ sodium dodecyl sulfate, $0.6 \mathrm{M}$ dithiothreitol, $0.012 \%$ bromophenol blue) and heating, for $5 \mathrm{~min}$, at $95^{\circ} \mathrm{C}$. Equal amounts of protein were separated by electrophoresis on sodium dodecyl sulfate-poly- 

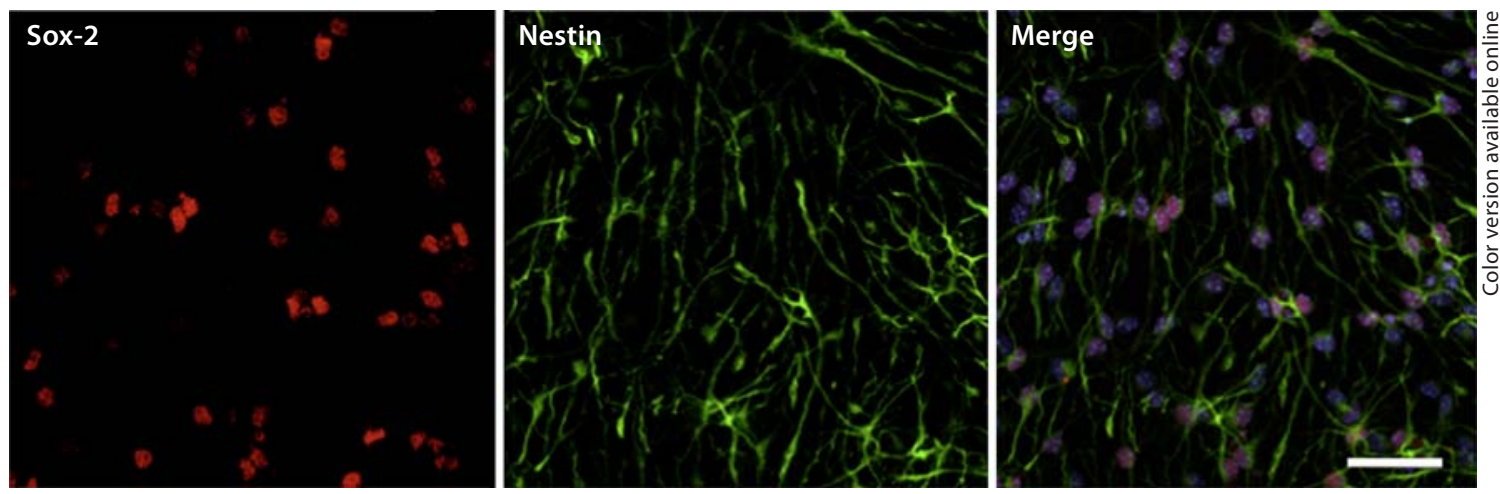

Fig. 1. Characterization of SVZ stem cell cultures. Representative laser scanning confocal images of SVZ cells labeled against Sox-2 (red) and nestin (green) are shown. Nuclei were labeled with Hoechst 33342 (blue). Scale bar: $45 \mu \mathrm{m}$. Colors refer to the online version only.

acrylamide gels, and transferred electrophoretically to polyvilydene difluoride membranes. These were then blocked for $1 \mathrm{~h}$ at room temperature in Tris-buffered saline $(137 \mathrm{mM} \mathrm{NaCl}, 20 \mathrm{mM}$ Tris-HCl, pH 7.6) containing 0.1\% Tween 20 (TBS-T) and 3\% BSA. Incubations with primary antibodies (rabbit anti-phosphoERK1/2 or mouse anti-ERK1/2, 1:1,000; Cell Signaling, Danvers, Mass., USA) in TBS-T $1 \%$ BSA were performed overnight at $4{ }^{\circ} \mathrm{C}$. The membranes were subsequently incubated for $1 \mathrm{~h}$ at room temperature with alkaline phosphatase-linked secondary antibodies (anti-rabbit or anti-mouse IgG, 1:20,000) in TBS-T 1\% BSA. After extensive washing in TBS-T with $0.5 \%$ BSA, immunoreactive bands were visualized on a VersaDoc 3000 Imaging System (BioRad, Hercules, Calif., USA) following incubation of the membrane with enhanced chemifluorescence reagent for $5 \mathrm{~min}$. The results are expressed as the percentage of control of phosphoERK/total ERK ratio.

\section{Statistical Analysis}

Data are expressed as means \pm SEM. Statistical significance was determined by using two-tailed $t$ tests or one-factor analysis of variance (ANOVA) as appropriate, followed by post hoc Bonferroni's or Dunnet's tests, as indicated in the figure legends and in the text. Differences were considered significant when $\mathrm{p}<0.05$.

\section{Results}

\section{Characterization of SVZ Primary Cultures}

Cells isolated from the SVZ were cultured as described previously (see Materials and Methods), and plated on poly-L-lysine-coated coverslips for 5 days. At this stage the cells were immunoreactive for the transcription factor Sox-2, essential for the self-renewal of undifferentiated stem cells, and nestin, a neural precursor cell marker. The percentage of double-labeled cells was approximately $70 \%$, suggesting that the majority of cells remain undifferentiated before being used for experiments (fig. 1). This abundance of undifferentiated SVZ cells is similar to that observed in SVZ primary cultures used in previous studies investigating the effects of $\mathrm{NO}$ on cell proliferation by our group [20] as well as by others [18, 29].

\section{NO Increases Cell Proliferation via the Guanylyl Cyclase-cGMP Pathway}

To investigate the involvement of cGMP in the proliferative effect of $\mathrm{NO}$, we evaluated the incorporation of thymidine analogues (EdU or BrdU) by SVZ cell cultures following treatment with a NO donor (NOC-18). We have previously shown that treatment with NOC-18 in the range of 1-10 $\mu \mathrm{M}$ increases proliferation of SVZ cells, but whether cGMP is involved in NO-induced neural stem cell proliferation has not been addressed. We first investigated, by flow cytometry, the involvement of cGMP in the proliferative effect of $\mathrm{NO}$ after 6 or $24 \mathrm{~h}$ following treatment with NOC-18 $(10 \mu \mathrm{M})$. Exposure to NOC-18 for $6 \mathrm{~h}$ increased the incorporation of EdU to $133.4 \pm 5.12 \%$ of the control ( $p<0.001)$ (fig. $2 a)$. After 24 h of NOC-18 treatment we further increased the EdU incorporation to $165.3 \pm 10.2 \%$ of the control ( $p<0.001)$ (fig. $2 b)$. In control conditions (untreated cells) the percentage of EdUpositive cells (percentage of total living cells) was $2.4 \pm$ $0.7 \%$ at $6 \mathrm{~h}$ and $2.2 \pm 0.9 \%$ at $24 \mathrm{~h}$.

The involvement of cGMP in the proliferative effect of NOC-18 was evaluated using the guanylyl cyclase inhibitor ODQ. Treatment with ODQ prevented NO-induced EdU incorporation at $24 \mathrm{~h}(\mathrm{p}<0.05)$, compared to SVZ cells treated with NOC-18 alone (fig. 2b), suggesting that cGMP mediates the effect of NO on cell proliferation for 
a

$6 \mathrm{~h}$

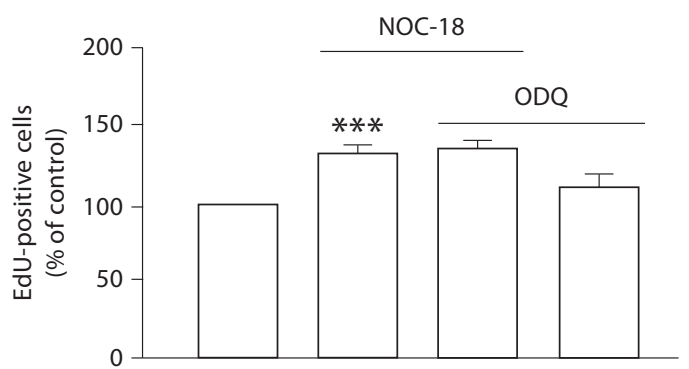

C

$6 \mathrm{~h}$

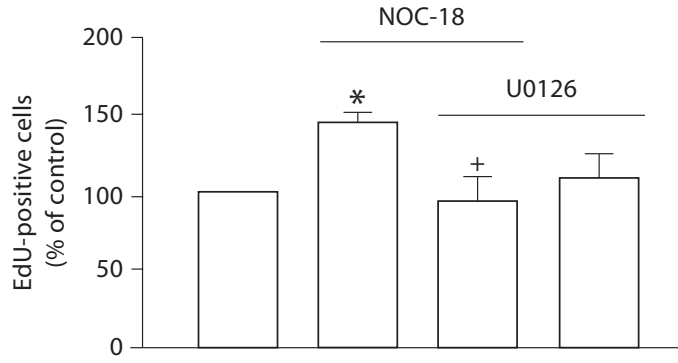

e
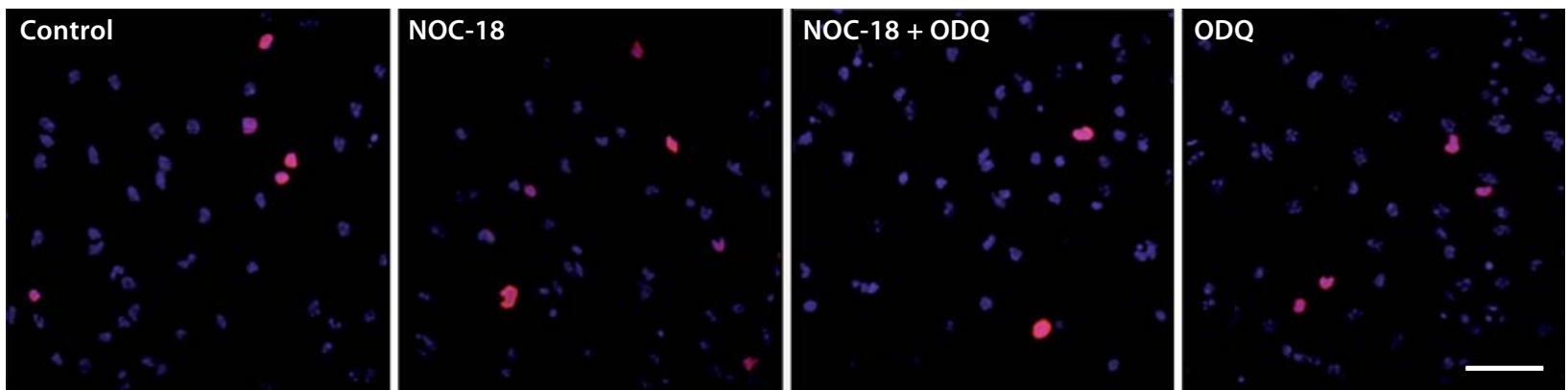

g

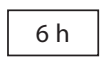

f

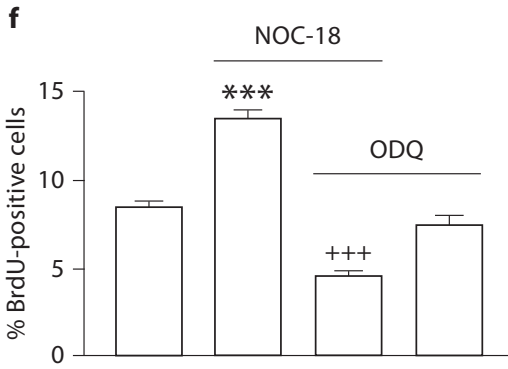

b

$24 \mathrm{~h}$

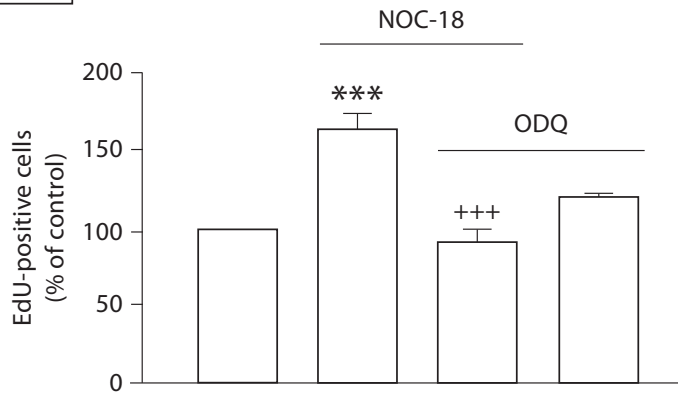

d

$24 \mathrm{~h}$

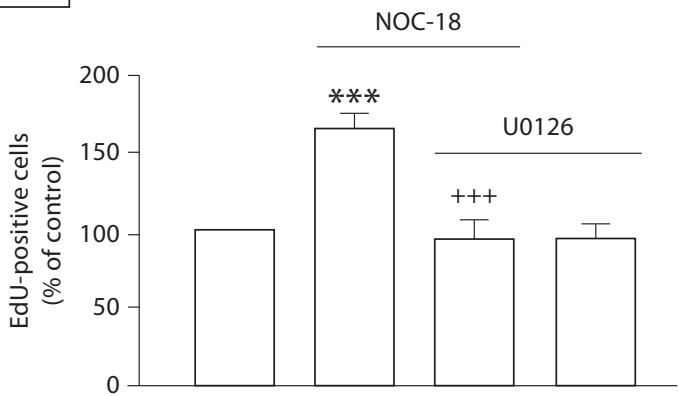

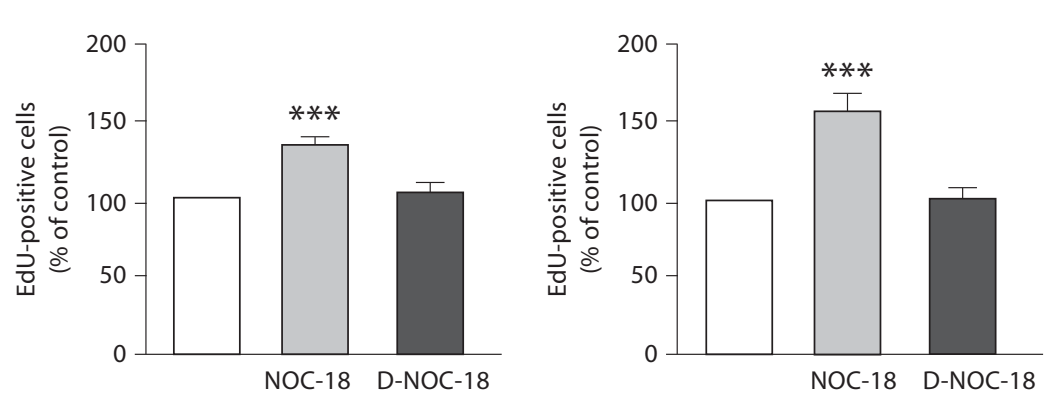

2 
Table 1. Determination of cGMP levels in neural stem cell cultures following exposure to NOC-18 for 6 or $24 \mathrm{~h}$

\begin{tabular}{llc}
\hline & Treatment & cGMP levels, fmol/10 $0^{6}$ cells \\
\hline $6 \mathrm{~h}$ & Control & $23.3 \pm 3.6$ \\
& NOC-18 & $257.8 \pm 70.1^{*}$ \\
& NOC-18+ ODQ & $25.2 \pm 3.5^{+}$ \\
& ODQ & $25.8 \pm 2.1$ \\
\hline $24 \mathrm{~h} \quad$ Control & $52.4 \pm 3.4$ \\
& NOC-18 & $266.3 \pm 16.7^{* *}$ \\
& NOC-18+ ODQ & $25.9 \pm 8.7^{++}$ \\
& ODQ & $25.2 \pm 11.9$ \\
& NOC-18+ U0126 & $308.1 \pm 32.7^{*}$ \\
& U0126 & $46.3 \pm 19.3$ \\
\hline
\end{tabular}

Data are expressed as means \pm SEM of 2-4 independent experiments. SVZ cells were treated with NOC-18 $(10 \mu \mathrm{M})$ with or without ODQ $(50 \mu \mathrm{M})$, or U0126 (1 $\mu \mathrm{M})$. ODQ and U0126 were added before and kept throughout exposure to NOC-18.

${ }^{*} \mathrm{p}<0.001$ or ${ }^{* *} \mathrm{p}<0.01$, significantly different from control; ${ }^{+} \mathrm{p}<0.001$ or $^{++} \mathrm{p}<0.01$, significantly different from NOC-18, one-way ANOVA (Bonferroni's post-test).

Fig. 2. NO increases cell proliferation via the guanylyl cyclasecGMP pathway for longer $(24 \mathrm{~h})$ but not for shorter $(6 \mathrm{~h})$ periods of cell exposure to NO. Cell proliferation following treatment with NOC-18 $(10 \mu \mathrm{M})$ in the absence or presence of $50 \mu \mathrm{M}$ ODQ for $6 \mathrm{~h}$ (a) or $24 \mathrm{~h}(\mathbf{b})$, evaluated by the incorporation of EdU and assessed by flow cytometry. Data are expressed as means \pm SEM of at least 6 independent experiments. One-way ANOVA (Bonferroni's post-test). ${ }^{* * *} \mathrm{p}<0.001$, significantly different from control; ${ }^{++} \mathrm{p}<0.001$, significantly different from NOC-18. EdU incorporation in neural stem cells following exposure to NOC-18 $(10 \mu \mathrm{M})$ in the absence or presence of $1 \mu \mathrm{M}$ U0126, a selective MEK1 and MEK2 inhibitor, for $6 \mathrm{~h}$ (c) or $24 \mathrm{~h}$ (d), as assessed by flow cytometry. Data are expressed as means \pm SEM of at least 4 independent experiments. One-way ANOVA (Bonferroni's posttest). ${ }^{*} \mathrm{p}<0.05$ or ${ }^{* * *} \mathrm{p}<0.001$, significantly different from control; ${ }^{+} \mathrm{p}<0.05$ or $^{+++} \mathrm{p}<0.001$, significantly different from NOC18. e Representative images of BrdU (red) incorporation in neural stem cells following exposure to NOC-18 $(10 \mu \mathrm{M})$ for $24 \mathrm{~h}$ in the absence or presence of a guanylyl cyclase inhibitor, ODQ (50 $\mu \mathrm{M})$. Nuclei are labeled by Hoechst 33342 (blue). Scale bar: $20 \mu \mathrm{m}$. f ODQ completely blocks the increase in the number of BrdUpositive cells. Data are expressed as means \pm SEM of at least 4 independent experiments. One-way ANOVA (Bonferroni's posttest). $* * * \mathrm{p}<0.001$, significantly different from control; ${ }^{+++} \mathrm{p}<0.001$, significantly different from $10 \mu \mathrm{M}$ NOC-18. g Decomposed NOC-18 (D-NOC-18) does not stimulate proliferation of SVZ-derived neural stem cells, unlike fresh NOC-18. Data are expressed as means \pm SEM of at least 4 independent experiments. One-way ANOVA (Dunnet's post-test). ${ }^{* *} \mathrm{p}<0.001$, significantly different from control. Colors refer to the online version only. the 24-hour period. However, the proliferative effect of NOC-18 after $6 \mathrm{~h}$ of treatment was not significantly affected by ODQ ( $p>0.05$; fig. $2 a$ ), suggesting that mechanisms other than guanylyl cyclase and cGMP are responsible for the proliferative effect of $\mathrm{NO}$ at $6 \mathrm{~h}$ of incubation with NOC-18. We then investigated whether the mitogen-activated kinase ERK1/2 was involved in the initial proliferative effect of $\mathrm{NO}$ at $6 \mathrm{~h}$. Inhibition of ERK1/2 activation by U0126 indeed prevented the increase in EdUpositive cells stimulated by NOC-18 at both $6 \mathrm{~h}(\mathrm{p}<0.05)$ and $24 \mathrm{~h}(\mathrm{p}<0.001)$ of treatment (fig. $2 \mathrm{c}, \mathrm{d})$.

We confirmed that ODQ prevented cell proliferation at $24 \mathrm{~h}$ following treatment with NOC-18 by evaluating the incorporation of BrdU by immunocytochemistry and microscopy analysis. Treatment with NOC-18 alone for $24 \mathrm{~h}$ increased the number of BrdU-positive cells from 8.5 $\pm 0.3 \%$ of total cells (control) to $13.4 \pm 0.5 \%(\mathrm{p}<0.001)$, and ODQ significantly blocked NOC-18-induced proliferation $(4.6 \pm 0.3 \%, \mathrm{p}<0.001)$ compared to NOC-18 alone (fig. 2e, f).

Unlike fresh NOC-18, decomposed NOC-18 did not stimulate proliferation of SVZ cells for either 6 or $24 \mathrm{~h}$ of treatment, as evaluated by EdU incorporation and detection by flow cytometry (fig. $2 \mathrm{~g}$ ).

We also analyzed intracellular cGMP levels in SVZ cells (table 1). In control conditions, cGMP levels were $23.3 \pm 3.6 \mathrm{fmol} \mathrm{cGMP} / 10^{6}$ cells at $6 \mathrm{~h}$ and $52.4 \pm 3.4 \mathrm{fmol}$ cGMP $/ 10^{6}$ cells at $24 \mathrm{~h}$. NOC- 18 alone increased cGMP levels more than 5 -fold for either 6 or $24 \mathrm{~h}$ of treatment $(\mathrm{p}<0.001)$. ODQ completely blocked NOC-18-induced cGMP production at both $6 \mathrm{~h}(\mathrm{p}<0.001)$ and $24 \mathrm{~h}(\mathrm{p}<$ $0.01)$ of treatment $(25.2 \pm 3.5$ and $25.9 \pm 8.7 \mathrm{fmol}$ cGMP $/ 10^{6}$ cells, respectively) when compared to NOC- 18 alone. We further investigated a possible crosstalk of the ERK1/2 pathway with the production of cGMP at $24 \mathrm{~h}$. A blockade of MEK1/2 by U0126 had no effect on cGMP production $(24 \mathrm{~h})$ compared to cultures treated with NOC-18 alone $(266.3 \pm 16.7 \mathrm{fmol}$ cGMP/10 6 cells $)$.

Since NO may induce apoptosis in neural stem cells [30], cell death was evaluated in the cultures following treatment with NOC-18. Flow cytometry analysis of nuclei stained with 7-AAD, as described in the Materials and Methods section, showed that NOC-18, alone or in combination with ODQ or U0126, did not significantly affect cell viability compared to untreated cultures (table 2).

\section{The cGMP Analogue 8-Br-cGMP Mimics the}

Proliferative Effect of NOC-18

Since cGMP appears to mediate the proliferative effect of $\mathrm{NO}$ at $24 \mathrm{~h}$, we assessed the proliferative effect of a 
Fig. 3. Effect of the cGMP analogue, 8-BrcGMP, on cell proliferation in SVZ neurosphere cultures. EdU incorporation in neural stem cells following exposure to 20 $\mu \mathrm{M} 8$-Br-cGMP for $6 \mathrm{~h} \mathrm{(a)} \mathrm{or} 24 \mathrm{~h}$ (b), as assessed by flow cytometry. Two-tailed $\mathrm{t}$ test. ${ }^{* *} \mathrm{p}<0.001$ or ${ }^{* *} \mathrm{p}<0.01$, significantly different from control. Data are expressed as means \pm SEM of at least 4 independent experiments. c 8-Br-cGMP (20 $\mu \mathrm{M})$ mimics the proliferative effect of $\mathrm{NO}$, as determined by BrdU incorporation following $24 \mathrm{~h}$ of treatment. Representative images of BrdU-positive cells (red) in neural stem cell cultures after exposure to 20 $\mu \mathrm{M} 8$-Br-cGMP, for $24 \mathrm{~h}$, are shown in the panels in c. Nuclei are labeled with Hoechst 33342 (blue). Scale bar: $20 \mu \mathrm{m}$. The data represent the percentage of BrdU-positive cells and are expressed as means \pm SEM of at least 3 independent experiments. Two-tailed t test. ${ }^{* * *} \mathrm{p}<0.01$, significantly different from control. Colors refer to the online version only.

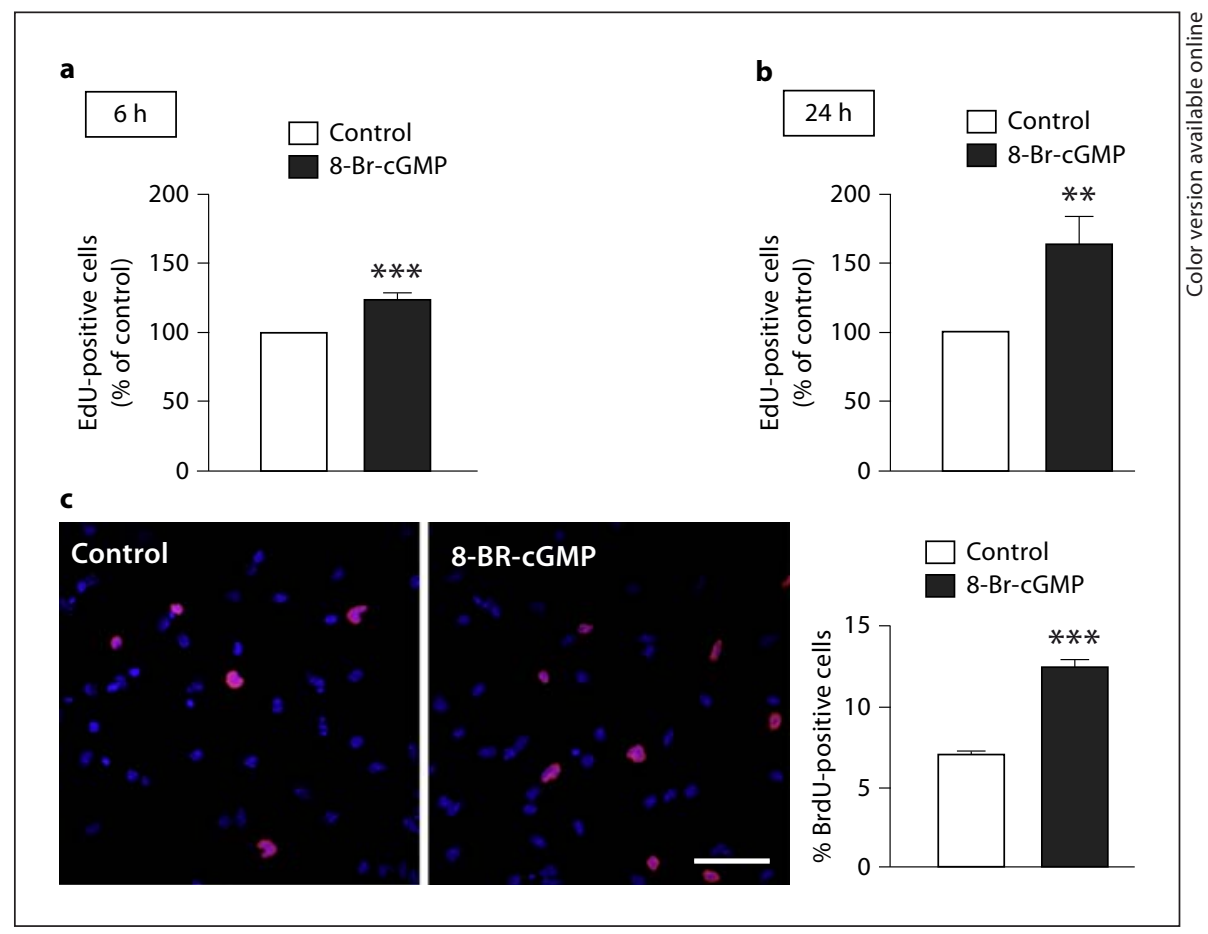

cGMP analogue, 8 -Br-cGMP (20 $\mu \mathrm{M})$, by flow cytometry. We observed a significant increase in EdU incorporation following 6 and $24 \mathrm{~h}$ of treatment with 8-Br-cGMP to $123.6 \pm 6.1 \%(\mathrm{p}<0.001$; fig. $3 \mathrm{a})$ and $162.7 \pm 20.1 \%$ ( $\mathrm{p}<0.01$; fig. $3 \mathrm{~b}$ ) of the control, respectively, compared to untreated cultures. We further confirmed the 24-hour observations by evaluating the incorporation of BrdU by immunocytochemistry and microscopy analysis. Treatment with 8 -Br-cGMP for $24 \mathrm{~h}$ significantly increased the number of BrdU-positive cells to $12.4 \pm 0.5 \%(\mathrm{p}<0.01)$ compared to control (7.0 $\pm 0.2 \%$; fig. $3 c)$.

\section{NO-Induced Activation of the Guanylyl Cyclase Pathway Is Independent of ERK/MAPK Pathway Activation}

To identify the intracellular pathways that mediate the proliferative effect of $\mathrm{NO}$, we investigated whether the guanylyl cyclase pathway is involved in the activation of the ERK/MAPK pathway. We showed that NOC-18 alone stimulates proliferation of SVZ cultures by activating ERK1/2 [20]. To evaluate how fast the phosphorylation of ERK1/2 occurs following exposure to NOC-18, we analyzed the phospho-ERK1/2:total ERK1/2 immunoreactivity ratio at several time points after the stimulus (at 5, 15,30 and $60 \mathrm{~min}$ ). The phosphorylation of ERK1/2 transiently increased to $138.1 \pm 8.4 \%$ of the control at $15 \mathrm{~min}$
Table 2. Cell viability in neural stem cell cultures following exposure to NOC-18 with or without U0126 or ODQ

\begin{tabular}{|c|c|c|}
\hline & Treatment & Live cells \\
\hline \multirow[t]{6}{*}{$6 \mathrm{~h}$} & Control & $90.9 \pm 1.4 \%$ \\
\hline & $10 \mu \mathrm{M}$ NOC-18 & $90.0 \pm 1.7 \%$ (n.s.) \\
\hline & $10 \mu \mathrm{M}$ NOC-18 + $1 \mu \mathrm{M}$ U0126 & $90.2 \pm 1.9 \%$ (n.s.) \\
\hline & $1 \mu \mathrm{M}$ U0126 & $92.6 \pm 1.2 \%$ (n.s.) \\
\hline & $10 \mu \mathrm{M}$ NOC- $18+50 \mu \mathrm{M}$ ODQ & $90.6 \pm 1.7 \%$ (n.s.) \\
\hline & $50 \mu \mathrm{M}$ ODQ & $90.0 \pm 1.6 \%$ (n.s.) \\
\hline \multirow[t]{6}{*}{$24 \mathrm{~h}$} & Control & $90.6 \pm 1.2 \%$ \\
\hline & $10 \mu \mathrm{M}$ NOC-18 & $91.0 \pm 1.4 \%$ (n.s.) \\
\hline & $10 \mu \mathrm{M}$ NOC-18 + $1 \mu \mathrm{M}$ U0126 & $90.1 \pm 1.4 \%$ (n.s.) \\
\hline & $1 \mu \mathrm{M}$ U0126 & $89.8 \pm 1.8 \%$ (n.s.) \\
\hline & $10 \mu \mathrm{M}$ NOC- $18+50 \mu \mathrm{M}$ ODQ & $91.4 \pm 1.1 \%$ (n.s.) \\
\hline & $50 \mu \mathrm{M}$ ODQ & $90.5 \pm 2.0 \%$ (n.s.) \\
\hline
\end{tabular}

Cell viability was assessed using the nuclear dye 7-AAD, detected by flow cytometry.

Data are expressed as means \pm SEM of at least 3 independent experiments.

p > 0.05 (nonsignificant; n.s.), not different from control, oneway ANOVA (Dunnett's post-test). 


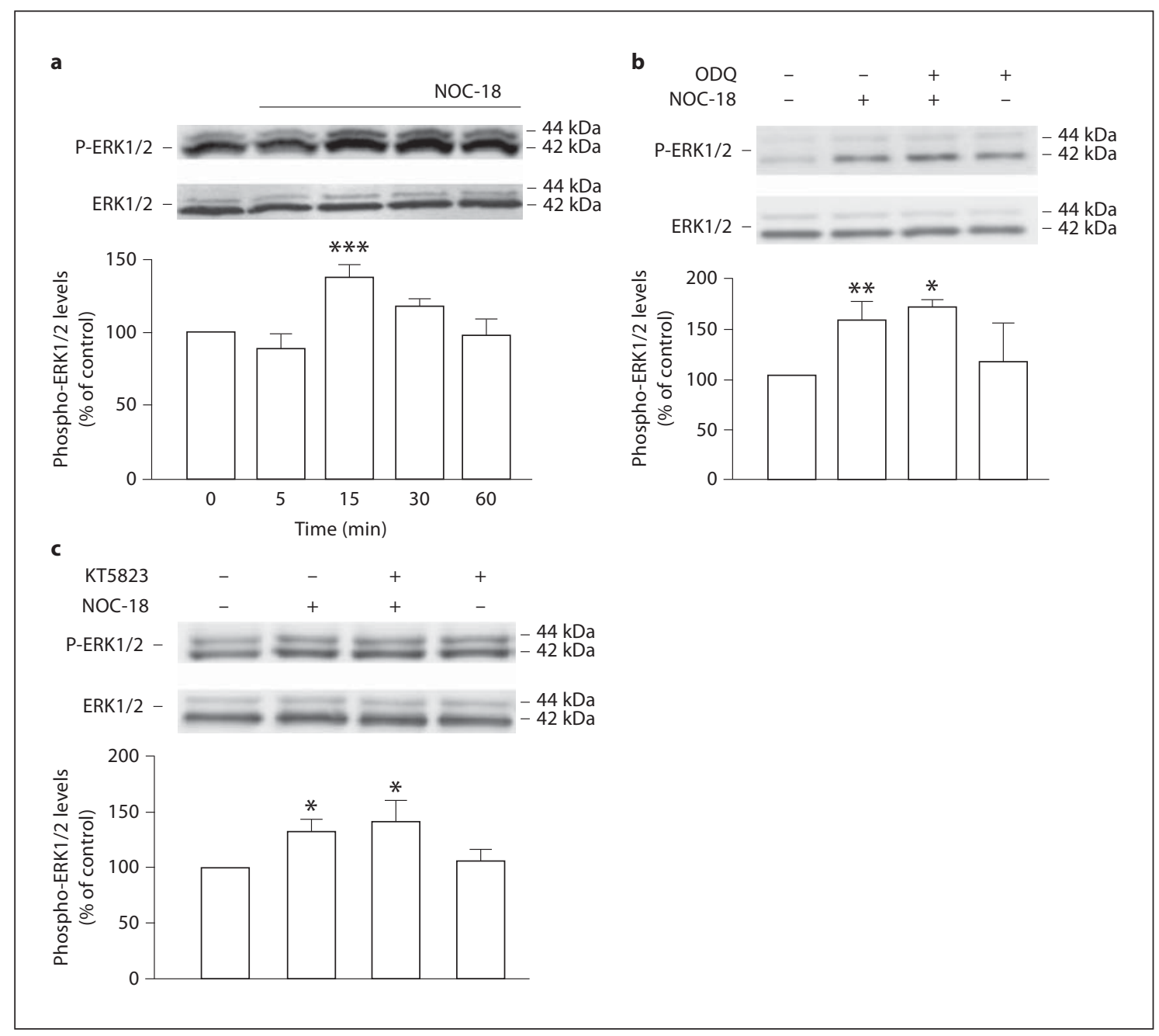

Fig. 4. NO activates the ERK/MAPK pathway in a cGMP-independent manner. a Time course analysis of the phosphorylation of ERK1/2 following exposure to NOC-18 (10 $\mu \mathrm{M})$. NOC-18 enhanced ERK1/2 phosphorylation as early as at $15 \mathrm{~min}$ of treatment. Data are expressed as means \pm SEM of at least 4 independent experiments. One-way ANOVA (Bonferroni's post-test). ${ }^{* * *} \mathrm{p}<0.001$, significantly different from control. b Western blot analysis of the involvement of guanylyl cyclase in the phosphorylation of ERK1/2, in lysates of neural stem cell cultures treated with NOC-18 for $15 \mathrm{~min}$. No effect of ODQ (50 $\mu \mathrm{M})$ on ERK1/2 phosphorylation was observed. Data are expressed as means \pm SEM of at least 3 independent experiments. One-way ANOVA (Bonferroni's post-test). ${ }^{* *} \mathrm{p}<0.01$ and ${ }^{*} \mathrm{p}<0.05$, significantly different from control. c No effect of the PKG inhibitor (KT5823; $1 \mu \mathrm{M})$ on the phosphorylation of ERK1/2 stimulated by exposure to NOC-18 $(10 \mu \mathrm{M})$ for $15 \mathrm{~min}$. One-way ANOVA (Bonferroni's post-test). ${ }^{*} \mathrm{p}<0.05$, significantly different from control. after treatment with $10 \mu \mathrm{M}$ NOC-18 (p < 0.001; fig. 4a). ODQ did not prevent the increase in the phosphorylation of ERK1/2 triggered by NOC-18 (164.3 $\pm 6.5 \%$ over the control), suggesting the activation of ERK by NO is an event independent of guanylyl cyclase (fig. $4 \mathrm{~b}$ ).

Since cGMP can activate the cGMP-dependent PKG, the involvement of PKG in the activation of ERK1/2 following treatment with NOC-18 was also evaluated. We observed that PKG does not appear to be involved in the early activation of ERK1/2 by exogenous NO, since KT5823, a PKG inhibitor, did not prevent the increased phosphorylation of ERK1/2 following exposure to NOC18 for 15 min (fig. 4c).

\section{The cGMP Analogue 8-Br-cGMP Activates the} ERK/MAPK Pathway via $P K G$

Since the cGMP analogue 8-Br-cGMP increased cell proliferation at 6 and $24 \mathrm{~h}$ in a similar manner to NOC-18, 


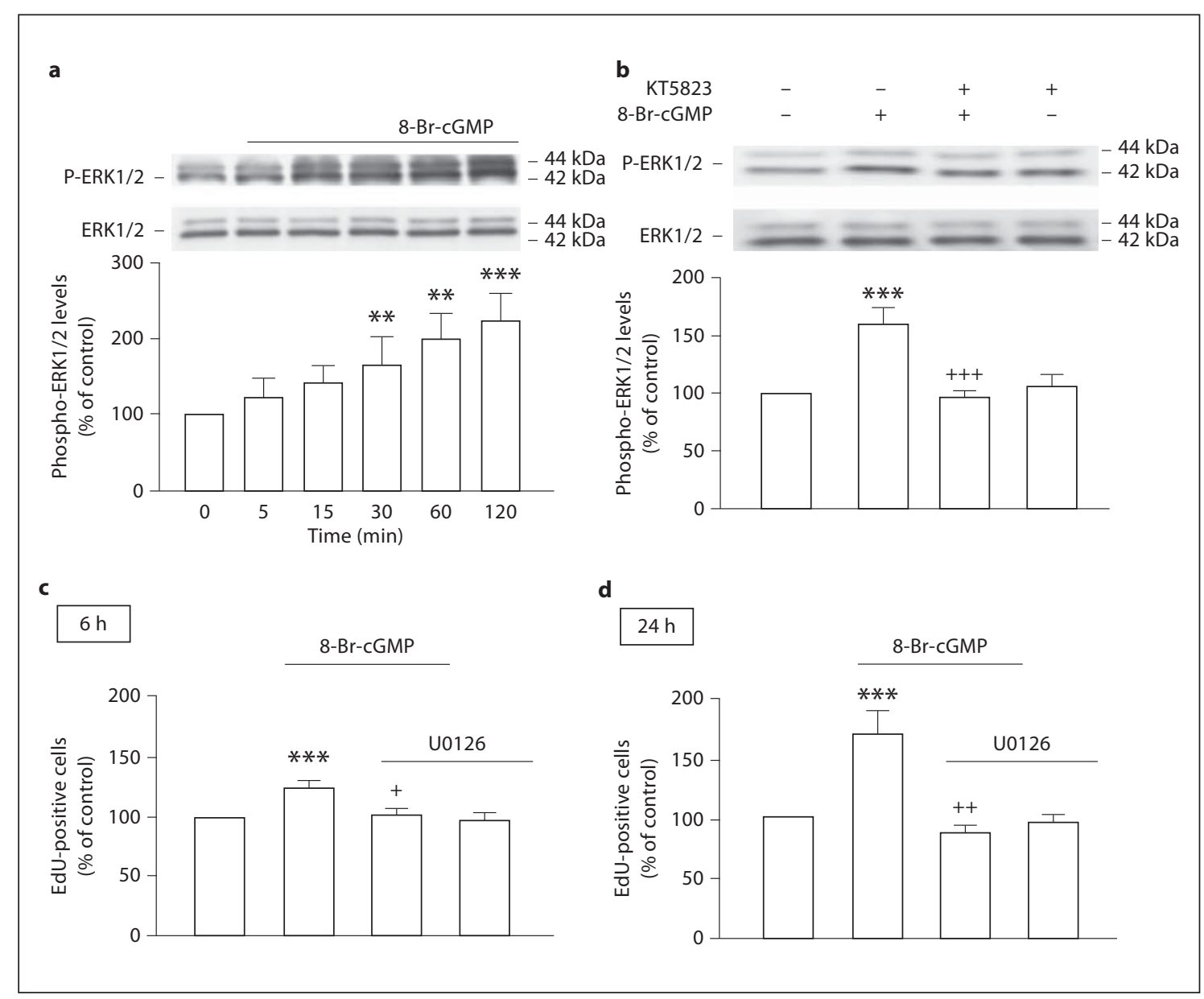

Fig. 5. The cGMP analogue 8-Br-cGMP increases the phosphorylation of ERK1/2. a Time course analysis of the phosphorylation of ERK1/2 in lysates of neural stem cell cultures upon treatment with $20 \mu \mathrm{M} 8$-Br-cGMP. Following exposure to 8-Br-cGMP there is a time-dependent increase in the phosphorylation of ERK1/2, followed for up to $120 \mathrm{~min}$. Data are expressed as means \pm SEM of at least 4 independent experiments. One-way ANOVA (Bonferroni's post-test). ${ }^{* *} \mathrm{p}<0.001$ and ${ }^{* *} \mathrm{p}<0.01$, significantly different from control. b KT5823 prevents the phosphorylation of ERK1/2 stimulated by treatment with 8 -Br-cGMP for $2 \mathrm{~h}$. One- way ANOVA (Bonferroni's post-test). ${ }^{* * *} \mathrm{p}<0.001$, significantly different from control; ${ }^{+++} \mathrm{p}<0.001$, significantly different from 8 -Br-cGMP. EdU incorporation in neural stem cells following exposure to 8 -Br-cGMP $(20 \mu \mathrm{M})$ in the absence or presence of $1 \mu \mathrm{M}$ U0126, for $6 \mathrm{~h}$ (c) or $24 \mathrm{~h}$ (d), as assessed by flow cytometry. Data are expressed as means \pm SEM of at least 4 independent experiments. One-way ANOVA (Bonferroni's post-test). ${ }^{* * *} \mathrm{p}<0.001$, significantly different from control; ${ }^{+} \mathrm{p}<0.05$ or $^{++} \mathrm{p}<0.01$, significantly different from 8-Br-cGMP. we also investigated the ability of 8-Br-cGMP to activate the ERK pathway. We analyzed the phospho-ERK1/2: total ERK1/2 immunoreactivity ratio at 5, 15, 30, 60 and 120 min following treatment with 8-Br-cGMP. There was a steady increase in the levels of phosphorylated ERK1/2 up to $2 \mathrm{~h}$ after treatment. At this time point, $20 \mu \mathrm{M}$ 8-Br-cGMP induced a two-fold increase in phosphoERK1/2:total ERK1/2 immunoreactivity ratio (221.1 \pm $12.3 \%$ of the control), as compared to untreated cultures (fig. 5a). Inhibition of PKG with KT5823 prevented
ERK1/2 phosphorylation following exposure to 8-BrcGMP for $2 \mathrm{~h}$ (fig. $5 \mathrm{~b}$ ), suggesting that PKG activation by 8-Br-cGMP is important for activation of ERK1/2 and occurs upstream of ERK1/2 phosphorylation. Likewise, the blockade of the ERK pathway by U0126 prevented EdU incorporation stimulated by treatment with 8 -Br-cGMP for $6 \mathrm{~h}(102.9 \pm 4.8 \%, \mathrm{p}<0.05$; fig. $5 \mathrm{c})$ or $24 \mathrm{~h}(87.0 \pm$ $5.8 \%, \mathrm{p}<0.01$; fig. $5 \mathrm{~d})$. 


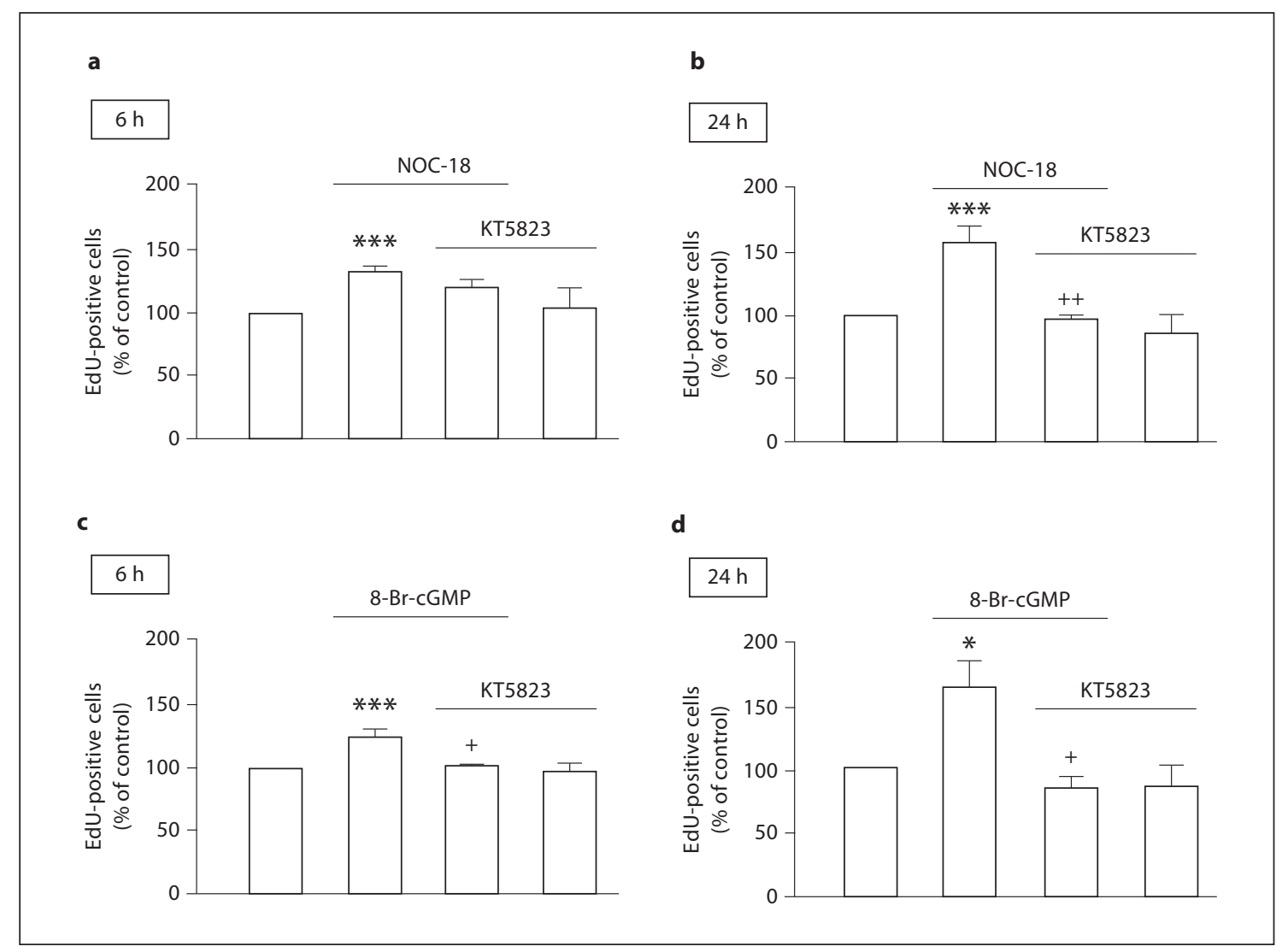

Fig. 6. Involvement of the $\mathrm{cGMP} / \mathrm{PKG}$ signaling pathway in the proliferation of neural stem cells. Cell proliferation following treatment with NOC-18 $(10 \mu \mathrm{M})$ in the absence or presence of $1 \mu \mathrm{M}$ KT5823, a selective PKG inhibitor, for $6 \mathrm{~h}$ (a) or $24 \mathrm{~h}$ (b), evaluated by incorporation of EdU and assessed by flow cytometry. Data are expressed as means \pm SEM of at least 4 independent experiments. One-way ANOVA (Bonferroni's post-test). ${ }^{* *} \mathrm{p}<$ 0.001 , significantly different from control; ${ }^{++} \mathrm{p}<0.001$, signifi-

PKG Contributes to Late but Not to Early Proliferation Induced by NO

The involvement of PKG in the proliferative effect of NO was studied by flow cytometry by evaluating the incorporation of EdU by SVZ cell cultures following treatment with NOC-18 or 8-Br-cGMP. The blockade of PKG by KT5823 had no effect on early proliferation $(6 \mathrm{~h})$ (fig. 6a), but significantly prevented the EdU incorporation induced by NOC- 18 treatment at $24 \mathrm{~h}(97.5 \pm 15.2 \%$, $\mathrm{p}<0.01)$, compared to cultures treated with NOC-18 alone (157.3 $\pm 12.4 \%$; fig. $6 \mathrm{~b})$. Concerning the exposure of SVZ cells to the cGMP analogue, the inhibition of PKG prevented the proliferation induced by 8 -Br-cGMP both for $6 \mathrm{~h}(102.9 \pm 2.0 \%, \mathrm{p}<0.05$; fig. $6 \mathrm{c})$ and $24 \mathrm{~h}$ cantly different from NOC-18. EdU incorporation in neural stem cells following exposure to 8 -Br-cGMP $(20 \mu \mathrm{M})$ in the absence or presence of $1 \mu \mathrm{M}$ KT5823, for $6 \mathrm{~h}$ (c) or $24 \mathrm{~h}$ (d), as assessed by flow cytometry. Data are expressed as means \pm SEM of at least 4 independent experiments. One-way ANOVA (Bonferroni's posttest). ${ }^{*} p<0.05$ or ${ }^{* * *} p<0.001$, significantly different from control; ${ }^{+} \mathrm{p}<0.05$, significantly different from 8 -Br-cGMP.

$(83.8 \pm 8.1 \%, \mathrm{p}<0.05$; fig. $6 \mathrm{~d})$ compared to 8 -Br-cGMP alone $(123.8 \pm 6.1$ and $162.7 \pm 20.1 \%$ for 6 and $24 \mathrm{~h}$, respectively). We further confirmed by immunocytochemistry the effect of the PKG inhibitor on the incorporation of BrdU in cultures treated with NOC-18 (fig. 7a) or with 8-Br-cGMP (fig. 7b). KT5823 significantly prevented BrdU incorporation following exposure for $24 \mathrm{~h}$ to either NOC-18 ( $\mathrm{p}<0.05)$ or 8 -Br-cGMP ( $<<$ $0.01)$.

Flow cytometry analysis of nuclei stained with 7-AAD, for the treatments described above, showed that KT5823 alone or in combination with NOC-18 or 8-Br-cGMP did not significantly affect the cell viability of SVZ cells compared to untreated cultures (table 3 ).
Carreira/Morte/Lourenço/Santos/ Inácio/Ambrósio/Carvalho/Araújo 


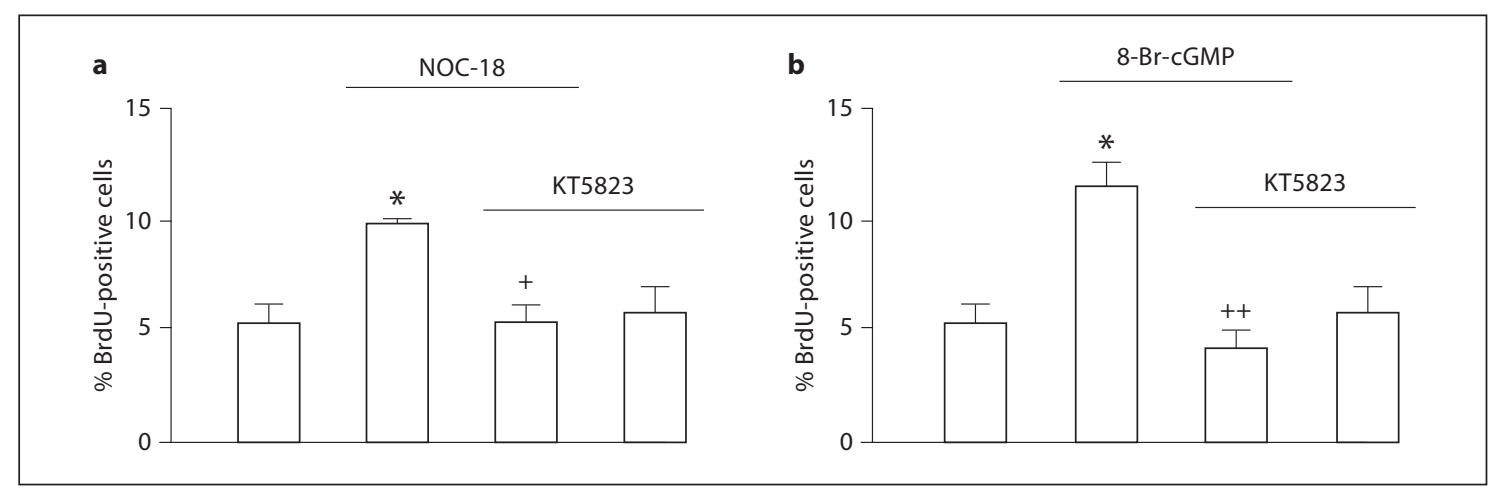

Fig. 7. The proliferative effect of NO is PKG-dependent. a Effect of the PKG inhibitor (KT5823; $1 \mu \mathrm{M}$ ) on cell proliferation, upon exposure to NOC-18 (10 $\mu \mathrm{M})$, for $24 \mathrm{~h}$. One-way ANOVA (Bonferroni's post-test). ${ }^{*} \mathrm{p}<0.05$, significantly different from control; ${ }^{+} \mathrm{p}<0.05$, significantly different from NOC-18. b KT5823 pre- vents cell proliferation stimulated by treatment with 8 -Br-cGMP for $24 \mathrm{~h}$. One-way ANOVA (Bonferroni's post-test). ${ }^{*} \mathrm{p}<0.05$, significantly different from control; ${ }^{+} \mathrm{p}<0.05$, significantly different from 8-Br-cGMP.
Table 3. Cell viability in neural stem cell cultures following exposure to NOC-18 or 8-Br-cGMP with or without KT5823

\begin{tabular}{lll}
\hline \multicolumn{2}{c}{ Treatment } & Live cells \\
\hline $6 \mathrm{~h}$ & Control & $89.7 \pm 1.1 \%$ \\
$10 \mu \mathrm{M}$ NOC-18 & $91.0 \pm 1.9 \%$ (n.s.) \\
$10 \mu \mathrm{M}$ NOC-18+1 $\mu \mathrm{M}$ KT5823 & $89.2 \pm 1.1 \%$ (n.s.) \\
$20 \mu \mathrm{M}$ 8-Br-cGMP & $93.0 \pm 1.2 \%$ (n.s.) \\
$20 \mu \mathrm{M}$ 8-Br-cGMP + $1 \mu \mathrm{M}$ KT5823 & $90.2 \pm 1.2 \%$ (n.s.) \\
$1 \mu \mathrm{M}$ KT5823 & $92.1 \pm 1.3 \%$ (n.s.) \\
\hline $24 \mathrm{~h}$ & Control & $87.9 \pm 1.9 \%$ \\
$10 \mu \mathrm{M}$ NOC-18 & $91.0 \pm 2.1 \%$ (n.s.) \\
$10 \mu \mathrm{M}$ NOC-18+1 $\mu \mathrm{M}$ KT5823 & $92.1 \pm 2.3 \%$ (n.s.) \\
$20 \mu \mathrm{M}$ 8-Br-cGMP & $89.9 \pm 0.8 \%$ (n.s.) \\
$20 \mu \mathrm{M}$ 8-Br-cGMP + 1 $\mu \mathrm{M}$ KT5823 & $90.0 \pm 1.2 \%$ (n.s.) \\
$1 \mu \mathrm{M}$ KT5823 & $93.5 \pm 1.1 \%$ (n.s.) \\
\hline
\end{tabular}

Cell viability was assessed using the nuclear dye 7-AAD, detected by flow cytometry.

Data are expressed as means \pm SEM of at least 3 independent experiments.

p > 0.05 (nonsignificant; $n . s$. ), not different from control, oneway ANOVA (Dunnett's post-test).

\section{Discussion}

In this work, we show that cGMP and PKG are involved in the late proliferative effect triggered by $\mathrm{NO}$ in neural stem cell cultures, since the inhibition of guanylyl cyclase or PKG abolishes cell proliferation induced by NO. Although cGMP and PKG were not involved in the early activation of ERK1/2, they were mandatory for the increase in cell proliferation following treatment with the NO donor NOC-18 for $24 \mathrm{~h}$. Moreover, the cGMP analogue 8-Br-cGMP also increased neural stem cell proliferation. We also found that the crosstalk between the ERK1/2 pathway and the PKG pathway differs when neural stem cells are treated directly with the NO donor or with the cGMP analogue.

Our results demonstrate that NO rapidly and transiently activates ERK1/2 in a cGMP-independent manner, since ODQ did not prevent ERK1/2 phosphorylation. Also, the blockade of guanylyl cyclase did not prevent the early proliferative effect of NOC-18 at 6 h. Furthermore, we have previously shown that phosphorylation and activation of ERK1/2 is essential for the proliferative effect of $\mathrm{NO}$, either at the early stages of cell proliferation following exposure to $\mathrm{NO}$ (as early as $30 \mathrm{~min}$ ) or for later endpoints $(24 \mathrm{~h})$ [20]. These data strongly suggest that the initial proliferation triggered by $\mathrm{NO}$ is dependent on the activation of the ERK1/2 pathway, does not require activation of guanylyl cyclase, and is not dependent on cGMP. This early proliferative effect is also independent of PKG, which does not contribute to either ERK phosphorylation or proliferation. Possibly, NO might directly activate components of the ERK pathway (upstream of ERK1/2) that are sensitive to NO signaling by S-nitrosylation of cysteine residues. For instance, p21Ras has a cysteine residue (Cys118) that is sensitive to NO, and when nitrosylated, p21Ras becomes activated [31,32].

Long-term exposure ( $24 \mathrm{~h}$ ) to NO increased cell proliferation in a cGMP-dependent manner. The blockade of 
guanylyl cyclase or PKG completely abolished the proliferative effect of $\mathrm{NO}$ at $24 \mathrm{~h}$, suggesting that cGMP and PKG signaling are essential for the proliferative effect of NO. Our data strongly suggest that the proliferative effect of $\mathrm{NO}$ is biphasic, i.e. an early increase in proliferation is dependent on the MAPK pathway and does not rely on guanylyl cyclase or PKG, and for later stages cGMP and PKG contribute heavily to the proliferation induced by NO. It is worth noting that the production of cGMP was independent of the MAPK pathway, since U0126 did not prevent the increase in cGMP levels observed following a 24-hour exposure to NOC-18.

The cGMP analogue 8-Br-cGMP also triggered cell proliferation, and our data show that PKG is important for this proliferative effect. 8-Br-cGMP also induced activation of ERK1/2, which was now sensitive to the inhibition of PKG, suggesting that phosphorylation of ERK1/2 following 8-Br-cGMP application to neural stem cells relies on a mechanism dependent on PKG. It remains to be established whether PKG directly activates ERK by phosphorylation. Furthermore, we observed that blocking ERK1/2 activation with U0126 prevents proliferation of neural stem cells following treatment with 8-Br-cGMP, suggesting that the activation of the MAPK pathway is responsible for the proliferative effect of the cGMP analogue. PKG is a serine/threonine kinase that is activated upon binding of cGMP, and NO-induced elevation of the intracellular levels of cGMP has been reported to directly regulate the activity of PKG [33-35]. PKG has been implicated in the regulation of gene expression as reviewed by Madhusoodanan and Murad [23]. Some studies suggest that the cGMP/PKG pathway is involved in the activation of the MAPK pathway, particularly ERK1/2 [36, 37], which appears to be the case in our study where neural stem cells are treated with a cGMP analogue. When the neural stem cells are treated with a NO donor, we observed that the initial ERK1/2 activation is independent of cGMP-dependent signaling to initiate the early proliferative events triggered by NO. For longer exposures, signaling via guanylyl cyclase and PKG gains relevance for the proliferation stimulated by NO.

The GC-cGMP pathway is the main effector pathway of the biological effects of $\mathrm{NO}$ as a second messenger. Although this pathway is expected to participate in the signaling events contributing to the proliferative effect of NO treatment in neural stem cells, most evidence up to now was circumstantial. Regarding the formation of newborn cells from stem cells, it was reported that the elevation of cGMP levels by PDE5 inhibition promoted PKG activation, enhancing the proliferation of mesen- chymal stem cells [38]. Other studies correlated the elevation of cGMP levels with the enhancement of neurogenesis $[25,26,39]$. Understanding how cGMP and its downstream target PKG contribute to the proliferative effect of NO can help in better targeting these systems to design well-grounded therapies for stimulating endogenous neurogenesis for brain repair purposes.

Altogether, we show that $\mathrm{NO}$ can activate two independent pathways in a biphasic manner that act to increase neural stem cell proliferation, initially the ERK/ MAPK pathway, and for later stages the guanylyl/cGMP/ PKG pathway. Although there is no evidence of crosstalk between these two pathways for the early effect of $\mathrm{NO}$, this possibility cannot be excluded for NO-induced cell proliferation at later stages. While the early proliferation of neural stem cells triggered by $\mathrm{NO}$ is independent of cGMP and PKG, the complete blockade of the proliferative effect of NO at later stages by inhibition of either guanylyl cyclase, PKG or ERK1/2 suggests a crosstalk between these different signaling pathways.

\section{Acknowledgments}

This work was supported by the Calouste Gulbenkian Foundation, L'Oréal, UNESCO, and the Foundation for Science and Technology (FCT, Portugal), COMPETE and FEDER (project PTDC/SAU-NEU/102612/2008). Bruno P. Carreira and Maria Inês Morte were supported by FCT, Portugal (fellowships SFRH/BPD/78901/2011, SFRH/BD/23754/2005 and SFRH/ $\mathrm{BD} / 38127 / 2007)$.

References

$\checkmark 1$ Whitney NP, Eidem TM, Peng H, Huang Y, Zheng JC: Inflammation mediates varying effects in neurogenesis: relevance to the pathogenesis of brain injury and neurodegenerative disorders. J Neurochem 2009;108: 1343-1359.

2 Monje ML, Toda H, Palmer TD: Inflammatory blockade restores adult hippocampal neurogenesis. Science 2003;302:1760-1765.

- 3 Ekdahl CT, Claasen JH, Bonde S, Kokaia Z, Lindvall O: Inflammation is detrimental for neurogenesis in adult brain. Proc Natl Acad Sci USA 2003;100:13632-13637.

4 Ekdahl CT, Kokaia Z, Lindvall O: Brain inflammation and adult neurogenesis: the dual role of microglia. Neuroscience 2009;158: 1021-1029.

5 Bengzon J, Kokaia Z, Elmer E, Nanobashvili A, Kokaia M, Lindvall O: Apoptosis and proliferation of dentate gyrus neurons after single and intermittent limbic seizures. Proc Natl Acad Sci USA 1997;94:10432-10437.
12
Carreira/Morte/Lourenço/Santos/ Inácio/Ambrósio/Carvalho/Araújo 
6 Parent JM, Yu TW, Leibowitz RT, Geschwind DH, Sloviter RS, Lowenstein DH: Dentate granule cell neurogenesis is increased by seizures and contributes to aberrant network reorganization in the adult rat hippocampus. J Neurosci 1997;17:3727-3738.

7 Parent JM, Lowenstein DH: Seizure-induced neurogenesis: are more new neurons good for an adult brain? Prog Brain Res 2002;135: 121-131.

8 Arvidsson A, Kokaia Z, Airaksinen MS, Saarma M, Lindvall O: Stroke induces widespread changes of gene expression for glial cell line-derived neurotrophic factor family receptors in the adult rat brain. Neuroscience 2001;106:27-41.

-9 Arvidsson A, Collin T, Kirik D, Kokaia Z, Lindvall O: Neuronal replacement from endogenous precursors in the adult brain after stroke. Nat Med 2002;8:963-970.

10 Kernie SG, Parent JM: Forebrain neurogenesis after focal ischemic and traumatic brain injury. Neurobiol Dis 2010;37:267-274.

-11 Jakubs K, Bonde S, Iosif RE, Ekdahl CT, Kokaia Z, Kokaia M, Lindvall O: Inflammation regulates functional integration of neurons born in adult brain. J Neurosci 2008;28: 12477-12488.

12 Thored P, Heldmann U, Gomes-Leal W, Gisler R, Darsalia V, Taneera J, Nygren JM, Jacobsen SE, Ekdahl CT, Kokaia Z, Lindvall O: Long-term accumulation of microglia with proneurogenic phenotype concomitant with persistent neurogenesis in adult subventricular zone after stroke. Glia 2009;57: 835-849.

$\checkmark 13$ Hoehn BD, Palmer TD, Steinberg GK: Neurogenesis in rats after focal cerebral ischemia is enhanced by indomethacin. Stroke 2005; 36:2718-2724.

14 Contestabile A, Ciani E: Role of nitric oxide in the regulation of neuronal proliferation, survival and differentiation. Neurochem Int 2004;45:903-914.

15 Packer MA, Stasiv Y, Benraiss A, Chmielnicki E, Grinberg A, Westphal H, Goldman SA, Enikolopov G: Nitric oxide negatively regulates mammalian adult neurogenesis. Proc Natl Acad Sci USA 2003;100:95669571.

16 Moreno-Lopez B, Romero-Grimaldi C, Noval JA, Murillo-Carretero M, Matarredona ER, Estrada C: Nitric oxide is a physiological inhibitor of neurogenesis in the adult mouse subventricular zone and olfactory bulb. J Neurosci 2004;24:85-95.
17 Matarredona ER, Murillo-Carretero M, Moreno-Lopez B, Estrada C: Nitric oxide synthesis inhibition increases proliferation of neural precursors isolated from the postnatal mouse subventricular zone. Brain Res 2004;995:274-284.

18 Torroglosa A, Murillo-Carretero M, Romero-Grimaldi C, Matarredona ER, CamposCaro A, Estrada C: Nitric oxide decreases subventricular zone stem cell proliferation by inhibition of epidermal growth factor receptor and phosphoinositide-3-kinase/Akt pathway. Stem Cells 2007;25:88-97.

19 Zhu DY, Liu SH, Sun HS, Lu YM: Expression of inducible nitric oxide synthase after focal cerebral ischemia stimulates neurogenesis in the adult rodent dentate gyrus. J Neurosci 2003;23:223-229.

20 Carreira BP, Morte MI, Inacio A, Costa G, Rosmaninho-Salgado J, Agasse F, Carmo A, Couceiro P, Brundin P, Ambrosio AF, Carvalho CM, Araujo IM: Nitric oxide stimulates the proliferation of neural stem cells bypassing the epidermal growth factor receptor. Stem Cells 2010;28:1219-1230.

21 Gomez-Pinedo U, Rodrigo R, Cauli O, Herraiz S, Garcia-Verdugo JM, Pellicer B, Pellicer A, Felipo V: cGMP modulates stem cells differentiation to neurons in brain in vivo. Neuroscience 2010;165:1275-1283.

22 Tegenge MA, Rockel TD, Fritsche E, Bicker G: Nitric oxide stimulates human neural progenitor cell migration via cGMP-mediated signal transduction. Cell Mol Life Sci 2011;68:2089-2099.

23 Madhusoodanan KS, Murad F: No-cGMP signaling and regenerative medicine involving stem cells. Neurochem Res 2007;32:681-694.

24 Zhang R, Wang Y, Zhang L, Zhang Z, Tsang W, Lu M, Chopp M: Sildenafil (Viagra) induces neurogenesis and promotes functional recovery after stroke in rats. Stroke 2002;33: 2675-2680.

-25 Zhang L, Zhang Z, Zhang RL, Cui Y, LaPointe MC, Silver B, Chopp M: Tadalafil, a long-acting type 5 phosphodiesterase isoenzyme inhibitor, improves neurological functional recovery in a rat model of embolic stroke. Brain Res 2006;1118:192-198.

-26 Wang L, Gang Zhang Z, Lan Zhang R, Chopp M: Activation of the PI3-K/Akt pathway mediates cGMP enhanced-neurogenesis in the adult progenitor cells derived from the subventricular zone. J Cereb Blood Flow Metab 2005;25:1150-1158.

-27 Araujo IM, Ambrosio AF, Leal EC, Santos PF, Carvalho AP, Carvalho CM: Neuronal nitric oxide synthase proteolysis limits the involvement of nitric oxide in kainate-induced neurotoxicity in hippocampal neurons. J Neurochem 2003;85:791-800.
28 Alvaro AR, Martins J, Araujo IM, Rosmaninho-Salgado J, Ambrosio AF, Cavadas C: Neuropeptide Y stimulates retinal neural cell proliferation - involvement of nitric oxide. J Neurochem 2008;105:2501-2510.

29 Covacu R, Danilov AI, Rasmussen BS, Hallen $\mathrm{K}$, Moe MC, Lobell A, Johansson $\mathrm{CB}$, Svensson MA, Olsson T, Brundin L: Nitric oxide exposure diverts neural stem cell fate from neurogenesis towards astrogliogenesis. Stem Cells 2006;24:2792-2800.

-30 Canals S, Casarejos MJ, Rodriguez-Martin E, de Bernardo S, Mena MA: Neurotrophic and neurotoxic effects of nitric oxide on fetal midbrain cultures. J Neurochem 2001;76: 56-68.

31 Lander HM, Hajjar DP, Hempstead BL, Mirza UA, Chait BT, Campbell S, Quilliam LA: A molecular redox switch on p21(ras). Structural basis for the nitric oxide-p21(ras) interaction. J Biol Chem 1997;272:4323-4326.

32 Deora AA, Hajjar DP, Lander HM: Recruitment and activation of Raf- 1 kinase by nitric oxide-activated Ras. Biochemistry 2000;39: 9901-9908.

-33 Fiscus RR, Rapoport RM, Murad F: Endothelium-dependent and nitrovasodilator-induced activation of cyclic GMP-dependent protein kinase in rat aorta. J Cyclic Nucleotide Protein Phosphor Res 1983;9:415-425.

34 Fiscus RR: Involvement of cyclic GMP and protein kinase $\mathrm{G}$ in the regulation of apoptosis and survival in neural cells. Neurosignals 2002;11:175-190.

- 35 Forstermann U, Gorsky LD, Pollock JS, Schmidt HH, Heller M, Murad F: Regional distribution of EDRF/NO-synthesizing enzyme(s) in rat brain. Biochem Biophys Res Commun 1990;168:727-732.

36 Zaragoza C, Balbin M, Lopez-Otin C, Lamas $\mathrm{S}$ : Nitric oxide regulates matrix metalloprotease-13 expression and activity in endothelium. Kidney Int 2002;61:804-808.

37 Ota KT, Pierre VJ, Ploski JE, Queen K, Schafe GE: The NO-cGMP-PKG signaling pathway regulates synaptic plasticity and fear memory consolidation in the lateral amygdala via activation of ERK/MAP kinase. Learn Mem 2008; 15:792-805.

38 Haider HK, Lee YJ, Jiang S, Ahmad RP, Ryon MD, Ashraf M: Phosphodiestrase inhibition with tadalafil provides longer and sustained protection of stem cells. Am J Physiol Heart Circ Physiol 2010;299:H1395-H1404.

39 Zhang RL, Zhang Z, Zhang L, Wang Y, Zhang C, Chopp M: Delayed treatment with sildenafil enhances neurogenesis and improves functional recovery in aged rats after focal cerebral ischemia. J Neurosci Res 2006; 83:1213-1219. 